\title{
Effects of memorizing Quran by heart (hifz) on later academic achievement
}

\author{
Dr. S. Farhana Jahangir \& Nazia Nawaz \\ Department of Psychology \\ Shaheed Benazir Bhutto Women University, Peshawar, Pakistan
}

Background: The current study was conducted to investigate the effects of memorizing Quran (hifz) in relation to academic achievement and sociocultural life of huffaz (students who memorize the Quran).

Method: For the study, a convenience sample of 36 huffaz $(\mathrm{N}=36)$ from different colleges and universities were approached.

Results: The results revealed a significant difference in academic achievement of huffaz before and after hifz. Moreover, the content analysis showed overall positive impact on education and socio-cultural life of huffaz.

Conclusion: In conclusion, hifz produces overall positive effects on socioculture life of Huffaz. Likewise, preliminary results suggest it also improves and enhances academic achievement of Huffaz in this setting. 